\title{
The methyltransferase G9a regulates HoxA9-dependent transcription in AML
}

\author{
Bernhard Lehnertz, ${ }^{1,2}$ Caroline Pabst, ${ }^{2}$ Le Su, ${ }^{1}$ Michelle Miller, ${ }^{3}$ Feng Liu, ${ }^{4}$ Lin Yi, ${ }_{1}^{1}$ Regan Zhang, \\ Jana Krosl, ${ }^{2}$ Eric Yung, ${ }^{2}$ Jeanette Kirschner, ${ }^{1}$ Patty Rosten, ${ }^{3}$ T. Michael Underhill, ${ }^{1}$ Jian Jin, ${ }^{4}$ \\ Josée Hébert, ${ }^{2,5}$ Guy Sauvageau, ${ }^{2}$ R. Keith Humphries, ${ }^{3}$ and Fabio M. Rossi ${ }^{1,6}$ \\ ${ }^{1}$ University of British Columbia, Biomedical Research Centre, Vancouver, British Columbia V6T 1Z3, Canada; ${ }^{2}$ University of \\ Montreal, Institute for Research in Immunology and Cancer, Montreal, Quebec H3T 1J4, Canada; ${ }^{3}$ Terry Fox Laboratory, BC \\ Cancer Agency, Vancouver, British Columbia V5Z 1L3, Canada; ${ }^{4}$ University of North Carolina at Chapel Hill, Center for \\ Integrative Chemical Biology and Drug Discovery, Chapel Hill, North Carolina 27599, USA; ${ }^{5}$ Leukemia Cell Bank of Quebec \\ (BCLQ), Maisonneuve-Rosemont Hospital, Montréal, Quebec H1T 2M4, Canada
}

\begin{abstract}
Chromatin modulators are emerging as attractive drug targets, given their widespread implication in human cancers and susceptibility to pharmacological inhibition. Here we establish the histone methyltransferase G9a/ EHMT2 as a selective regulator of fast proliferating myeloid progenitors with no discernible function in hematopoietic stem cells (HSCs). In mouse models of acute myeloid leukemia (AML), loss of G9a significantly delays disease progression and reduces leukemia stem cell (LSC) frequency. We connect this function of G9a to its methyltransferase activity and its interaction with the leukemogenic transcription factor HoxA9 and provide evidence that primary human AML cells are sensitive to G9A inhibition. Our results highlight a clinical potential of G9A inhibition as a means to counteract the proliferation and self-renewal of AML cells by attenuating HoxA9dependent transcription.
\end{abstract}

[Keywords: histone methylation; hematopoiesis; leukemia; Hox genes]

Supplemental material is available for this article.

Received September 25, 2013; revised version accepted January 6, 2014.

The involvement of epigenetic regulators like MLL (Tkachuk et al. 1992), EZH2 (Morin et al. 2010), DNMT3A (Ley et al. 2010), and TET2 (Delhommeau et al. 2009) in the pathology of human leukemias has stimulated a great deal of interest in identifying chromatin-modifying enzymes that can be targeted therapeutically (Arrowsmith et al. 2012; Dawson and Kouzarides 2012). For example, a catalytic inhibitor of DOT1L interferes with the oncogenic activity of MLL fusions often found in pediatric leukemias (Daigle et al. 2011). Furthermore, LSD1/KDM1A inhibition suppresses acute myeloid leukemia (AML) stem cell activity (Harris et al. 2012; Schenk et al. 2012), and disruption of the chromatin binding of Brd4 by a BET bromodomain inhibitor blocks $c-M y c$ expression and the proliferation of leukemic cells (Delmore et al. 2011; Zuber et al. 2011). To date, several inhibitors of histone methyltransferases and demethylases have been reported, including those that target G9a and GLP with high specificity (Kubicek et al. 2007; Vedadi et al. 2011; Yuan et al. 2012). G9a/GLP uniquely catalyze mono- and dimethylation of histone 3 on Lys9 (H3K9me1/2) (Tachibana et al. 2002,

${ }^{6}$ Corresponding author

E-mail fabio@brc.ubc.ca

Article is online at http://www.genesdev.org/cgi/doi/10.1101/gad.236794.113.
2005), a highly abundant chromatin mark in mammalian cells. G9a/GLP take part in a number of corepressor complexes, and $\mathrm{H} 3 \mathrm{~K} 9 \mathrm{me} 2$ is enriched at inactive loci (Barski et al. 2007; Dong et al. 2008) and CpG islands (Lienert et al. 2011). In addition, G9a can activate transcription at least in part by acting as a cofactor for the Mediator complex (Chaturvedi et al. 2012). Interestingly, H3K9me2-enriched domains are mostly devoid of H3K27me3 mediated by Ezh1/2 (Lienert et al. 2011), suggesting that G9a/GLP-dependent pathways govern the expression of genes involved in cell differentiation in addition to those that are subject to PRC2-dependent repression. This has been demonstrated in certain contexts, as G9a mediates T-helper cell diversification (Lehnertz et al. 2010) and embryonic stem cell (ESC) differentiation (Feldman et al. 2006). Furthermore, G9A/GLP inhibition delays the differentiation of human hematopoietic stem cells (HSCs) ex vivo (Chen et al. 2012), suggesting additional roles in early hematopoiesis. Despite recent ad-

(C) 2014 Lehnertz et al. This article is distributed exclusively by Cold Spring Harbor Laboratory Press for the first six months after the full-issue publication date (see http://genesdev.cshlp.org/site/misc/terms.xhtml). After six months, it is available under a Creative Commons License (Attribution-NonCommercial 3.0 Unported), as described at http:// creativecommons.org/licenses/by-nc/3.0/. 
vances in delineating biological roles of G9a/GLP, a detailed characterization of these enzymes during hematopoiesis has not been reported.

\section{Results}

\section{Selective requirement for G9a in hematopoietic} progenitor cells

To confirm the expression of G9a in the hematopoietic system, we performed quantitative RT-PCR (qRT-PCR) analyses from FACS-purified hematopoietic subpopulations and detected high expression of $G 9 a$ in hematopoietic stem and progenitor cells (HSPCs), at levels comparable with mouse ESCs, and the lowest expression in mature myeloid and lymphoid cells (Supplemental Fig. S1). We then investigated the biological importance of $G 9 a$ in the hematopoietic system using $G 9 a^{f 1}$ mice (Fig. 1A; Lehnertz et al. 2010) crossed with Vav-Cre transgenic mice to obtain $G 9 a^{+/ f 1}$; Vav-Cre and G9a $a^{f l / f 1}$; Vav-Cre mice [G9a $a^{+/-(V a v)}$ and $G 9 a^{-1-}$ (Vav), hereafter]. As expected (Stadtfeld and Graf 2005; Gan et al. 2010), Vav-Cre-mediated excision in G9a $a^{-1-(\text { Vav) }}$ mice harboring a ROSA26-YFP (R26-YFP) Cre reporter was specific to hematopoietic cells and fully penetrant (Supplemental Fig. S2a-c). Consistent with previous reports (Tachibana et al. 2002, 2005), deletion of G9a resulted in a characteristic reduction in GLP and H3K9me2 levels in bone marrow-derived macrophages (BMMs) (Fig. 1B). G9 $a^{-1-(\text { Vav) }}$ mice also exhibited efficient deletion of $G 9 a$ in lymphoid cells, were born at normal frequency, and did not display any overt hematological abnormalities (Lehnertz et al. 2010).

We first investigated the function of G9a-deficient progenitor cells and evaluated the ability of bone marrow cells from $G 9 a^{+/-}{ }^{(\mathrm{Vav})}$ and $G 9 a^{-/-}$(Vav) mice to form colonies in cytokine-containing methylcellulose medium. While no difference in colony-forming unit (CFU) numbers (Fig. 1C) and phenotypes (Fig. 1D) was observed, the total cell output of G9a-deficient progenitors was drastically decreased (Fig. 1E). This was the result of a reduction in the size of individual colonies, most of which contained $<500$ cells (Fig. 1F,I).

To assess the activity of G9a-deficient HSCs, we generated mixed bone marrow chimeras with R26-YFP labeled $G 9 a^{+/-(\text {Vav) }}$ or $G 9 a^{-/-(\text {Vav })}$ cells in competition with $R 26-Y F P^{-}$; G9 $a^{f l / f l}$ cells (Fig. 1H; Supplemental Fig. S2d). Interestingly, we observed only a modest, nonsignificant difference in the relative output of $G 9 a^{+/-(V a v)}$ and $G 9 a^{-/-(\text {Vav) }}$ cells in the examined lineages 8 wk after transplantation. (Fig. 1I). However, this trend was no longer detectable $18 \mathrm{wk}$ after transplantation (Fig. 1J), suggesting that $G 9 a$ is not essential for the function of long-term repopulating HSCs (LT-HSCs).

\section{Loss of G9a impairs AML progression and leukemia stem cell (LSC) self-renewal in vivo}

To investigate G9a function in AML cells, which partially resemble myeloid progenitors (Krivtsov et al. 2006), we generated leukemias from knockout and heterozygous HSPCs by retroviral expression of HoxA9 and Meis1 (A9M)
(Supplemental Fig. S3; Kroon et al. 1998), two genes frequently overexpressed in human AML (Lawrence et al. 1999). Importantly, G9a and GLP were expressed in $G 9 a^{+/-(\text {Vav) }}$; A9M cells, and G9a expression was entirely ablated in $G 9 a^{-1-(\text { Vav)}}$; $A 9 M$ cells (Fig. 2A). While all recipients of $G 9 a^{+/-}(\mathrm{Vav}) ; A 9 M$ control cells rapidly advanced to end-stage AML, only 10 of 15 recipients of G9a $a^{-1-(\text { Vav) }}$; $9 M$ cells succumbed to AML, albeit with delayed kinetics (median survival 111 d vs. 75 d) (Fig. 2B). In addition, clonal analysis of HoxA9/Meis1 proviral DNA in the $G 9 a^{-1-(\text { Vav) }}$ cohort revealed identical integration patterns in more than one recipient, indicative of a reduced repertoire of self-renewing LSC clones (Fig. $2 \mathrm{C}$ ). To confirm this notion, we performed an in vivo limiting dilution assay (LDA) using bone marrow cells harvested from end-stage leukemic mice (Fig. 2D) and found that the frequency of LSCs among $G 9 a^{-/-}$(Vav); $A 9 M$ cells was reduced $\sim 20$-fold (Fig. 2 E).

We also generated $A 9 M$ leukemias from $G 9 a^{f l / f 1} ; M x-C r e^{+}$ mice, allowing the inducible deletion of $G 9 a$ in vivo following pIpC treatment (Supplemental Fig. S4a). pIpC treatment per se had no effect in primary recipients of $G 9 a^{f l /+(M x)} ; A 9 M$ cells (Supplemental Fig. S4b). In contrast, deletion of $G 9 a$ in secondary leukemia recipients of $G 9 a^{f l / f 1(M x)}$; $A 9 M$ cells led to a dramatic reduction in circulating leukemic cells after $12 \mathrm{~d}$ (Fig. 2E,F) and a significantly increased median survival of pIpC-treated mice (44 d vs. 23.5 d) (Fig. 2G). Importantly, G9a deficiency similarly delayed disease progression of $M N 1$ induced or $M L L$-AF9-induced experimental AML (Supplemental Fig. S5a,b), suggesting that this enzyme acts through a general mechanism and plays a role in multiple leukemias.

\section{G9a regulates expansion and differentiation of $A M L$ cells through its methyltransferase activity}

We additionally assessed the effects of G9a deletion on AML cells in vitro. $G 9 a^{-/-(\text {Vav) }} ; A 9 M$ cells displayed a substantial growth impairment, with a $>2.5$-fold increase in population doubling time $(\sim 37 \mathrm{~h}$ vs. $14 \mathrm{~h})$, resulting in a vastly reduced cumulative cell output compared with controls (Fig. 3A,B). This correlated with significantly more cells in $G_{1} / G_{0}$ but no increase in apoptosis (Fig. 3C; Supplemental Fig. S6). Importantly, loss of p53 did not rescue this growth deficiency, indicating that a p53-dependent senescence pathway was not responsible for this phenotype (Fig. 3A). To determine whether the catalytic activity of G9a was required for efficient AML cell proliferation, we reintroduced wild-type or a methyltransfer-

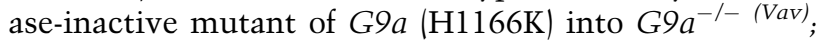
$A 9 M$ cells using an MSCV-ires-GFP (MIG) retroviral vector (Fig. 3D). Infection with MIG-G9 ${ }^{W T}$ conferred a competitive growth advantage to transduced $\left(\mathrm{GFP}^{+}\right)$over untransduced $\left(\mathrm{GFP}^{-}\right)$cells as indicated by their rapid takeover of the culture. In contrast, control-infected (empty MIG) and MIG G9 $a^{H 1166 K}$-infected cells displayed no growth advantage or even a slight disadvantage, respectively (Fig. 3E,F). Likewise, reintroduction of $G 9 a^{W T}$ but not $G 9 a^{H 1166 K}$ in $G 9 a^{-/-(V a v)}$; $A 9 M$ cells restored 

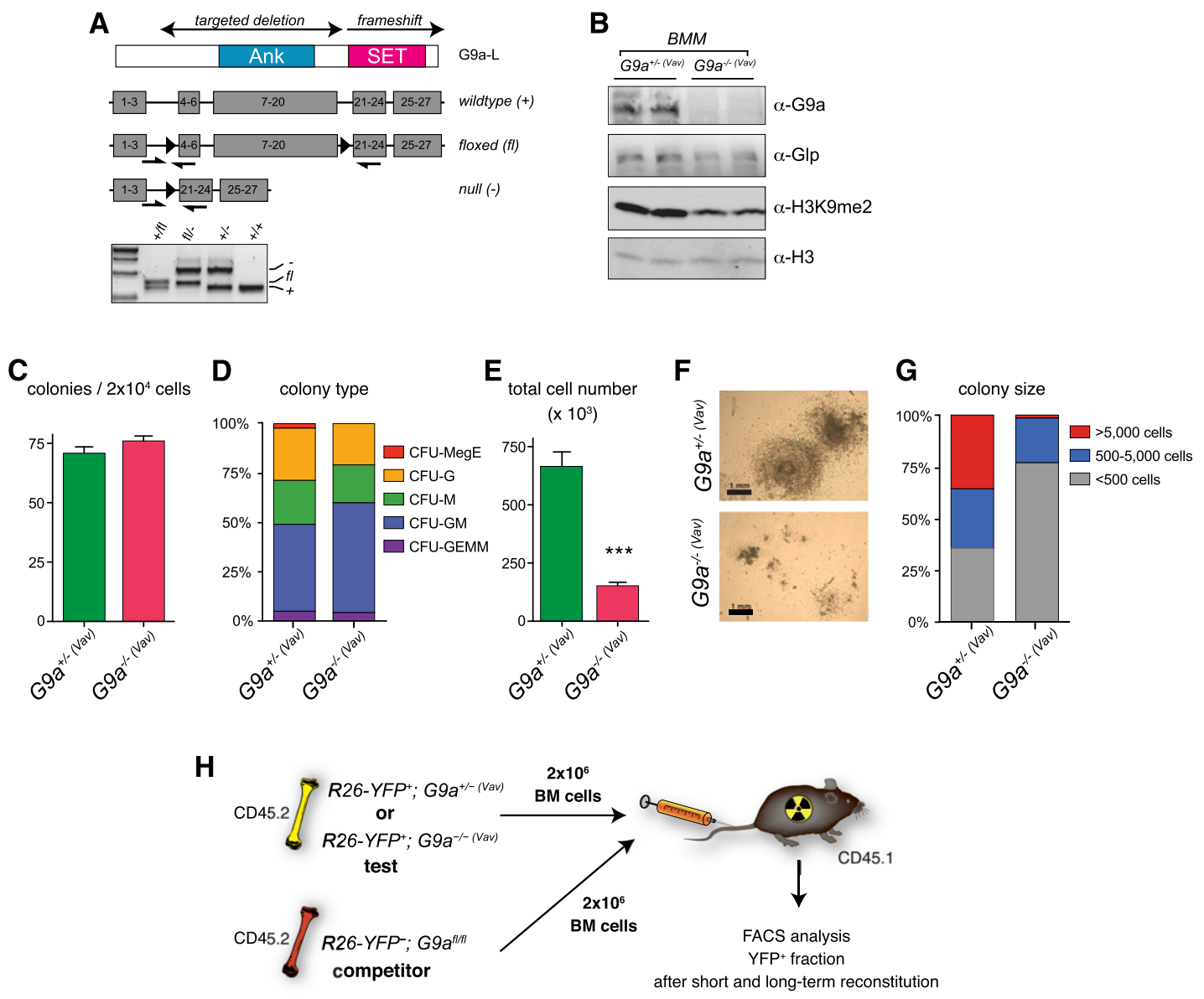

I

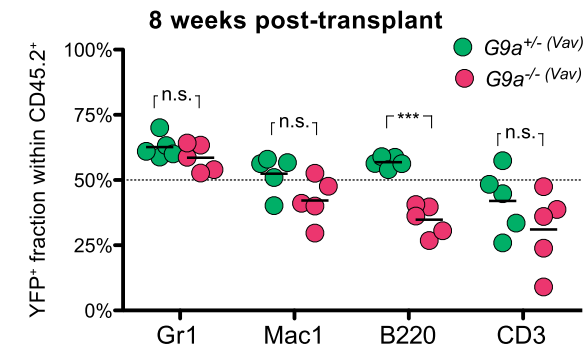

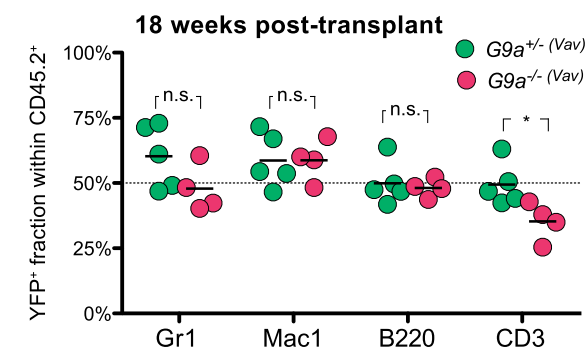

Figure 1. Characterization of G9a-deficient hematopoiesis. (A) Schematic representation of the G9a knockout strategy. Exons 4-20 were flanked by loxP sites to delete the central region of the gene and result in a frameshift in the SET domain coding region. Mice were routinely genotyped by PCR as shown. (B) Efficient inactivation of the targeted G9a locus in BMMs from G9a-1-(Vav) mice. Whole-cell lysates from BMMs were analyzed by Western blot. The absence of G9a and a characteristic decrease in GLP and H3K9me2 levels were observed. $(C)$ Normal number of colony-forming cells (CFCs) in $G 9 a^{-1-(V a v)}$ mice. Whole bone marrow cells $\left(2 \times 10^{4}\right)$ were plated in methylcellulose-based medium containing SCF, IL3, IL6, and Epo. The numbers of colonies at day 8 of culture were comparable between the $G 9 a^{-1-(\text { Vav })}$ and $G 9 a^{+/-(\text {Vav })}$ groups. $(D)$ Normal distribution of CFC types in $G 9 a^{-1-(\text { Vav) }}$ mice. The relative distribution of megakaryocyte/erythrocyte (MegE), granulocytic (G), macrophage (M), granulocyte/macrophage (GM), and granulocyte/erythrocyte/ macrophage/megakaryocyte (GEMM) CFCs was assessed in methylcellulose cultures from $G 9 a^{-/-(\text {Vav) }}$ and G9a $a^{+/-(V a v)}$ bone marrow cells. No significant differences in the presence of CFUs were detectable in the absence of G9a. (E) Decreased cellular output of G9adeficient progenitors. The total cell number of 8 -d cultures starting from $2 \times 10^{4} G_{9} a^{-/-(V a v)}$ and $G 9 a^{+/-(V a v)}$ whole bone marrow cells was assessed. $G 9 a^{-1-(\text { Vav })}$ cultures consistently yielded four to five fewer cells in total and in average per colony. A representative experiment is shown; $n=4$. (F) Representative CFU-GMs of $G 9 a^{+/-(\text {Vav) }}$ and $G 9 a^{-1-(\text { Vav) }}$ origin are shown. (G) G9a is required for the activity of highly proliferative progenitors. $G 9 a^{+/-(\text {Vav })}$ and $G 9 a^{-1-(\text { Vav })}$ colony sizes were estimated and scored as low $(<500$ cells), intermediate (500-5000 cells), and high-proliferative (>5000 cells) categories. Highly proliferative clones are essentially absent in $G 9 a^{-1-(\text { Vav })}$ bone marrow. $(H)$ Experimental strategy to assess HSC function in the absence of G9a. Bone marrow cells $\left(2 \times 10^{6}\right)$ from $G 9 a^{+/-(V a v)}$; R26-YFP $P^{+}$or $G 9 a^{-/-(V a v)}$; R26-YFP $P^{+}$test mice were mixed at a 50:50 ratio with YFP ${ }^{-}$competitor $\left(G 9 a^{f l / f 1}\right)$ bone marrow cells and transplanted into lethally irradiated congenic CD45.1 hosts. The relative chimerism in recipient mice was assessed by FACS analysis using YFP fluorescence and lineage-specific surface makers as indicated in Supplemental Figure S2d. (I) Summary of competitive bone marrow transplantation experiment 8 and $18 \mathrm{wk}$ post-transplant. One representative experiment of two experiments is shown, individual bone marrow recipients are represented by dots, and significant differences by unpaired $t$-tests are indicated. One recipient of $G 9 a^{-/-(\mathrm{Vav})} / G 9 a^{f l / f 1}$ cells was sacrificed due to dermatitis 10 wk post-transplant. 
Lehnertz et al.

A

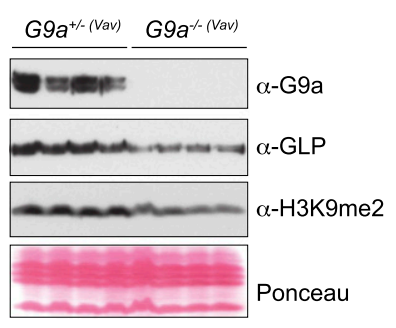

D

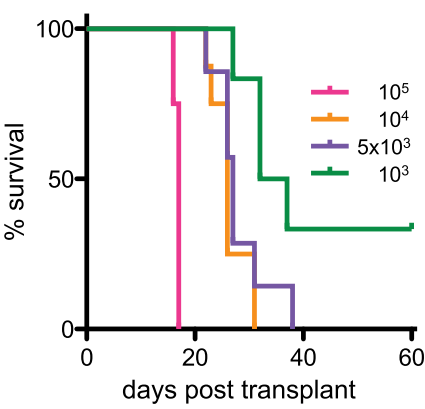

F
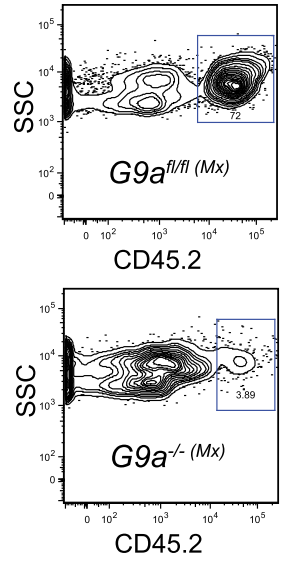

B

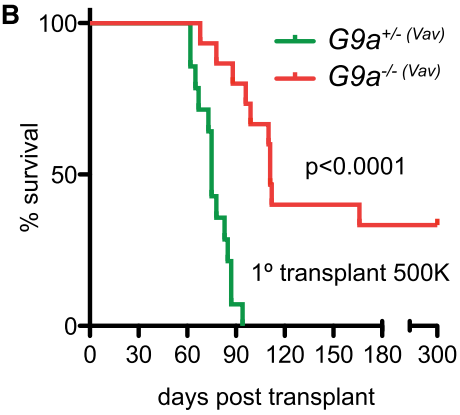

C

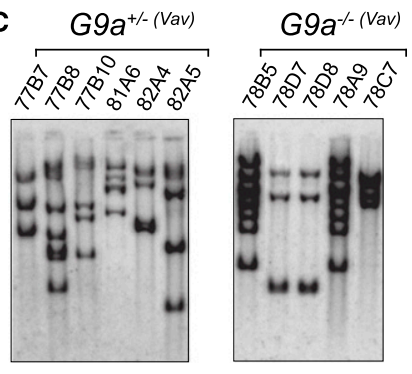

E

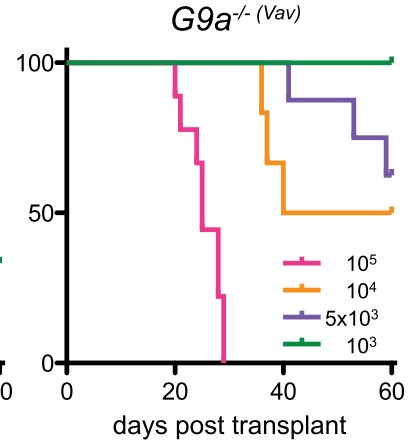

LDA summary

\begin{tabular}{|c|c|c|}
\cline { 2 - 3 } \multicolumn{1}{c|}{} & \multicolumn{2}{c|}{$\begin{array}{c}\text { Leukemic/Transplanted } \\
\text { Mice }\end{array}$} \\
\hline Cell dose & $\mathrm{G}^{\text {Ma }}{ }^{+/ \text {(Vav) }}$ & $\mathrm{G}^{-1-\text { (Vav) }}$ \\
\hline $10^{5}$ & $4 / 4$ & $8 / 8$ \\
\hline $10^{4}$ & $8 / 8$ & $3 / 6$ \\
\hline $5 \times 10^{3}$ & $7 / 7$ & $2 / 8$ \\
\hline $10^{3}$ & $4 / 6$ & $0 / 8$ \\
\hline
\end{tabular}

\begin{tabular}{|l|c|c|}
\cline { 2 - 3 } \multicolumn{1}{c|}{} & \multicolumn{2}{c|}{ Confidence Intervals (95\%) } \\
\cline { 2 - 3 } \multicolumn{1}{c|}{} & $\mathrm{G}^{+} \mathrm{a}^{+/ \text {-(Vav) }}$ & $\mathrm{G} 9 \mathrm{a}^{-/ \text {(Vav) }}$ \\
\hline lower $\mathrm{Cl}$ & $1 / 2,224$ & $1 / 37,836$ \\
\hline Estimate & $\mathbf{1 / 8 7 8}$ & $\mathbf{1 / 1 6 , 8 3 4}$ \\
\hline higher $\mathrm{Cl}$ & $1 / 347$ & $1 / 7,490$ \\
\hline
\end{tabular}

G

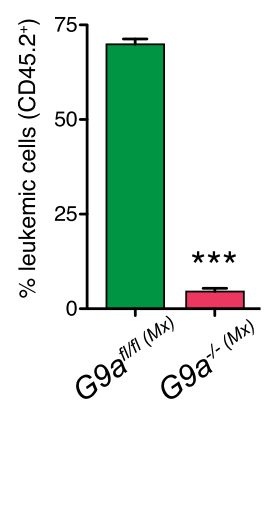

H

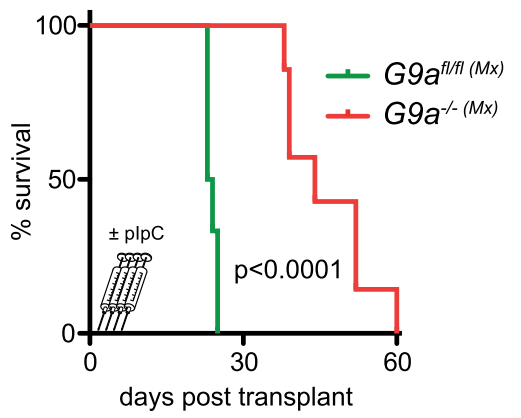

Figure 2. G9a deficiency affects AML progression in vivo. (A) Efficient abrogation of G9a expression in G9a $a^{-1-(V a v)}$ AML cells. 5-FUactivated $G 9 a^{+-(\text {Vav) }}$ and $G 9 a^{-/-(\text {Vav })}$ HSPCs were infected with a HoxA9-ires-Meis1 PGK-Neo-expressing MSCV vector and G418selected for $5 \mathrm{~d}$ in vitro. Whole-cell lysates were analyzed by Western blot. No remaining G9a expression and reduced GLP and H3K9me2 levels were detectable. Four independent $A 9 M$ cell lines for each genotype were analyzed. (B) Decreased AML penetrance and increased disease latency in the absence of G9a. HSPCs of the indicated genotypes were infected with HoxA9/Meis1 as described above and transplanted at a dose of $5 \times 10^{5}$ cells per irradiated CD45.1 recipient. Proportion of disease-free survival is plotted. $(n=14$ for control; $n=15$ for knockout cohort); $P<0.0001$ using log rank test. (C) Proviral integration patterns in DNA of $G 9 a^{+/-}($Vav) and $G 9 a^{-1-(\mathrm{Vav})}$ mice suggest that $G 9 a^{-/-(\text {Vav) }}$ leukemias contain a limited repertoire of initiating cells. Genomic DNA from bone marrow cells was digested with SpeI, transferred to a nylon membrane, and hybridized with a Neo probe to detect individual integrants. $(D)$ G9 $a^{-1-(\text { Vav) }}$ leukemia shows reduction in LSC frequency. Bone marrow cells from leukemic mice shown in $A$ were transplanted at increasing dilution $\left(10^{5}\right.$ to $10^{3}$ cells) in lethally irradiated secondary recipients to assess frequency of LSCs. (Left panel) G9a ${ }^{+/-}$(Vav) leukemia was used as control. (Right panel) $G 9 a^{-1-(V a v)}$ leukemia. (E) LDA to estimate LSC frequencies. Survival ratios are listed and were analyzed using an LDA software (WEHI-ELDA). Estimated LSC frequencies (indicated) decrease 20-fold in the absence of G9a. $(F, G)$ Requirement for $G 9 a$ in AML maintenance. Leukemic $G 9 a^{f l / f 1(M x)}$; $A 9 M$ bone marrow cells $\left(10^{5}\right)$ from a diseased primary recipient were transplanted into irradiated secondary recipients. Control mice $\left(G 9 a^{f l / f l(M x)}\right)$ were left untreated, whereas test mice $\left(G 9 a^{-/-}(M x)\right)$ received four injections of $\mathrm{pIpC}$ to stimulate Cre expression and abrogate G9a expression. The abundance of peripheral AML cells was assessed by CD45.2 staining in recipients $12 \mathrm{~d}$ after pIpC treatment. G9a inactivation in the $G 9 a^{-1-(M x)}$ cohort resulted in a significant decrease of peripheral AML cells. Representative FACS plot is shown in $E$; statistical summary is shown in $F(n=6$ for untreated; $n=7$ for treated; $P<0.0001$ using unpaired $t$-test $).(H)$ A significant delay in AML progression in the $G 9 a$-depleted cohort $\left(G 9 a^{-/-(M x)}\right)$ was observed $(n=6$ for untreated; $n=7$ for treated; $P<0.0001$ using $\log$ rank test). 
A

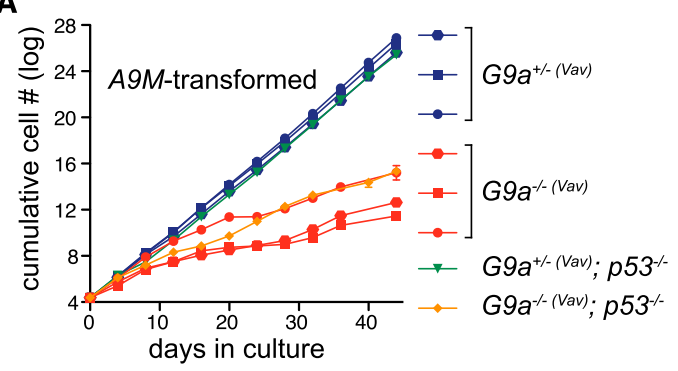

D $\mathrm{MSCV}$ ires GFP

(MIG)

LTR ires GFPLTR

LTR G9a ${ }^{\text {WT }}$ ires GFPLTR

LTR G9a ${ }^{H 1166 K}$ ires GFP LTR

E $48 \mathrm{~h}$ post-infection

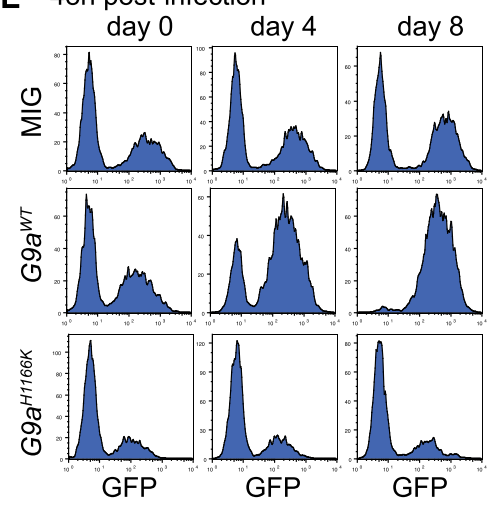

$\mathbf{F}$

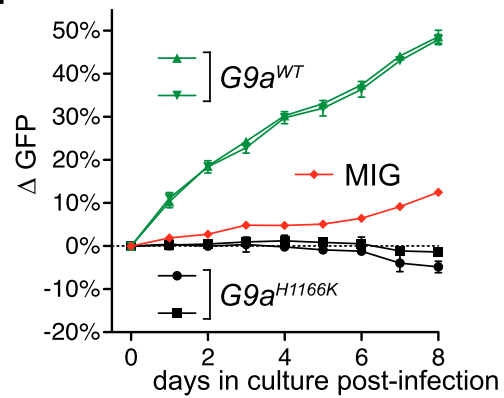

B

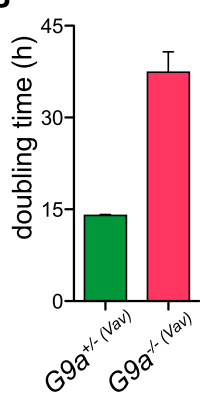

C
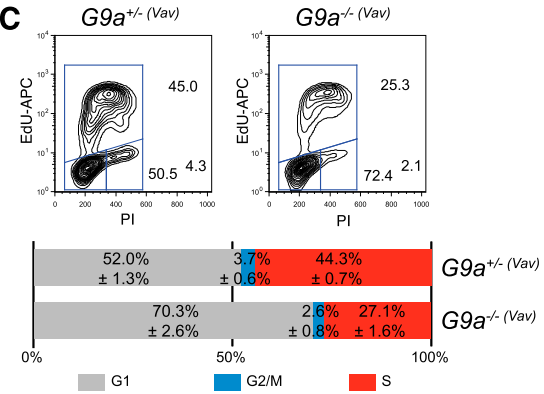

G
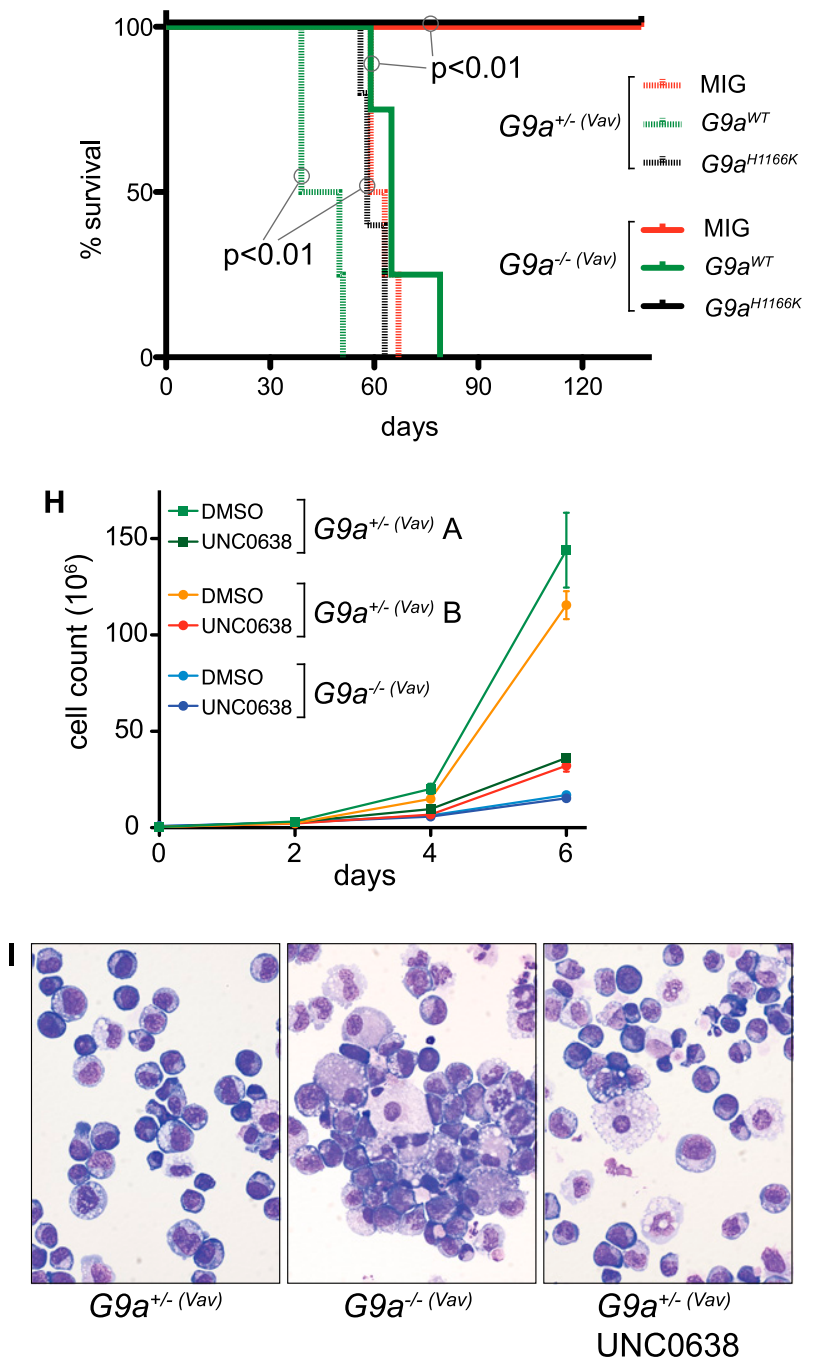

Figure 3. G9a activity determines the proliferation rate of mouse AML cells. (A) Impaired proliferation of AML cells deficient in G9a. $A 9 M$ cells of the indicated genotypes were generated as in Figure 2A. The resulting leukemia cell lines were maintained in culture to assess their growth kinetics. G9a-deficient cultures were characterized by severely reduced proliferation. Compound deletion of $p 53$ did not rescue this growth defect. Each individual experiment originating from distinct donor bone marrow is represented by a separate curve. $(B)$ The average population doubling times of cultures from $A$ was calculated and plotted. A $>2.5$-fold increase in net doubling time was observed in G9a-deficient cultures. (C) HoxA9/Meis1-expressing $G 9 a^{-1-(V a v)}$ cells display a decrease in cell cycle progression, indicated by a significant reduction in EdU incorporation compared with $G 9 a^{+/-(V a v)}$ control cultures. $(D)$ Schematic representation of the used MSCVbased rescue constructs. $A 9 M$ cells were infected with either empty MIG retrovirus or MIG-expressing wild-type or mutant $G 9 a$. $(E, F)$ Rescue of $G 9 a^{-1-(\text { Vav)} ; A 9 M}$ cell growth by wild-type but not methyltransferase-inactive mutant $G 9 a^{H 1166 K}$ in vitro. A proliferative advantage of transduced $\left(\mathrm{GFP}^{+}\right)$cells over the remainder of the culture was observed only in $G 9 a^{W T}$-infected samples. $(G) \mathrm{G} 9 \mathrm{a}$ levels and activity determine AML disease progression in vivo. $G 9 a^{+/-(\text {Vav)}}$; $A 9 M$ or $G 9 a^{-/-}{ }^{(\text {Vav })}$; $A 9 M$ cells were infected with the indicated retroviruses and transplanted into lethally irradiated recipient mice. Reintroduction of $G 9 a^{W T}$ into $G 9 a^{-1-}$ (Vav); $A 9 M$ cells restores normal AML progression. Ectopic expression of $G 9 a^{W T}$ in $G 9 a^{+-(\text {Vav) }}$; $A 9 M$ cells accelerates AML progression. $n=4$ for each group; significant log rank $P$-values are indicated. $(H)$ UNC0638-mediated G9a/GLP inhibition recapitulates the $G 9 a^{-1-}($ Vav) phenotype. Treatment with $800 \mathrm{nM}$ UNC0638 selectively inhibits the growth of $A 9 M$-expressing $G 9 a^{+/-}$(Vav) but not $G 9 a^{-/-}$(Vav) cells, demonstrating the specificity of this compound. (I) G9a inactivation results in myeloid differentiation of HoxA9/Meis1 leukemic cells. $G 9 a^{+/-(\text {Vav) }}$ and $G 9 a^{-1-(\text { Vav) }}$ were either control-treated (DMSO) or subjected to $1 \mu \mathrm{M}$ UNC0638 for 5 d. Cytospin preparations indicate a loss of blast-like morphology and a concomitant increase in myeloid differentiation. 
their ability to initiate AML in transplanted recipient mice (Fig. 3G). Notably, ectopic expression of $G 9 a^{W T}$ in G9a $a^{+/-}$(Vav); $A 9 M$ cells significantly accelerated AML progression, demonstrating that elevated levels of G9a increase AML aggressiveness in vivo (Fig. 3G). These results suggested that catalytic inhibition of G9a should mimic the phenotype observed in $69 a^{-1-(\text { Vav) }}$ cells. Indeed, treatment with the G9a/GLP inhibitor UNC0638 (Vedadi et al. 2011) inhibited the growth of $G 9 a^{+/-}$(Vav); $A 9 M$ but not $G^{9} a^{-1-(\text { Vav); }} A 9 M$ cells in vitro (Fig. $3 \mathrm{H}$ ). Furthermore, whereas $G 9 a^{+/-(\text {Vav) }} ; A 9 M$ cells exhibited a characteristic blast-like morphology with a high nucleus to cytosol ratio and the absence of granular cytosolic structures, both G9a-deficient and UNC0638-treated AML cells displayed a significant degree of myeloid differentiation (Fig. 3I). Taken together, these results indicate that the methyltransferase activity of G9a is critical to maintain high proliferation rates and the incomplete differentiation characteristic of AML cells.

\section{G9a regulates HoxA9-dependent gene expression}

G9a was previously linked to the transforming activity of Evi-1/Prdm3 (Goyama et al. 2009), a Zn finger containing H3K9-specific monomethyltransferase (Pinheiro et al. 2012) whose expression is independently correlated with poor prognosis in AML. Since Evi-1 is critical for the function of HSCs as well as normal and transformed progenitors (Goyama et al. 2008), whereas G9a is not required for HSC function, we thus reasoned that G9a likely plays important roles independently of its connection with Evi-1. A number of considerations led us to hypothesize that G9a may exert its role in AML cells by facilitating HoxA9-dependent gene expression. First, although HoxA9 plays important roles in HSPCs, HoxA9-deficient mice are viable and, compared with Evi-1 mutants, display a relatively mild hematopoietic phenotype (Lawrence et al. 1997, 2005) that in some

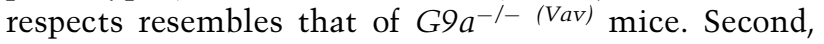
HoxA9 elicits its oncogenic activity in AML cells by enforcing self-renewal and impairing myeloid differentiation, both of which were affected in $G 9 a^{-1-(V a v)} \mathrm{AML}$ cells. Third, overexpression of wild-type but not catalytically dead G9a accelerates the pathogenesis of $\operatorname{Hox} A 9 /$ Meis1-driven AML, suggesting that endogenous levels of G9a are limiting in this model and that it may play a direct role in HoxA9-regulated transcription mediated through its methyltransferase activity. To assess this hypothesis, we first asked whether a physical interaction between HoxA9 and G9a takes place. To this end, we performed coimmunoprecipitation studies using Flag- and HA-tagged versions of G9a and HoxA9, respectively. Indeed, we could detect a robust interaction between G9a and HoxA9 following immunoprecipitation with anti-Flag or anti-HA antibodies (Fig. 4A), suggesting that G9a is recruited to sites of HoxA9-dependent transcription. Next, we investigated whether the methyltransferase activity of G9a is required to facilitate HoxA9-dependent gene expression in mouse AML cells. To this end, we performed microarray analysis to assess changes in gene expression in HoxA9- and Meis1-expressing leukemic cells treated with UNC0638 for $5 \mathrm{~d}$ in comparison with mock-treated controls (Supplemental Fig. S7a). We then compared this data set to that of a study that used an estrogen receptorcoupled version of HoxA9 (HoxA9-ER) together with Meis1 to generate mouse AML cells. These cells were initially cultured in the presence of 4-hydroxy-tamoxifen (4OHT) to allow HoxA9 function and then transferred to medium lacking 4OHT for $5 \mathrm{~d}$ prior to measuring HoxA9-dependent gene expression (Supplemental Fig. S7b; Huang et al. 2012). Strikingly, gene set enrichment analysis (GSEA) revealed a highly significant overlap between genes that responded to UNC0638 treatment in HoxA9/Meis1 and those that responded to 4OHT withdrawal in HoxA9-ER/Meis1 cells (Fig. 4B,C). This was consistent with a decrease in the expression of LSCassociated genes and an increase in granulocyte-specific genes in response to UNC0638 or 4OHT withdrawal in the respective data sets (Supplemental Fig. S7c,d), confirming the loss of a self-renewal signature and increased myeloid differentiation in both of these conditions. To assess whether the overlap between G9a-dependent and HoxA9-dependent gene expression changes was due to a direct effect on HoxA9 target genes or a secondary effect due to increased differentiation in both conditions, we restricted GSEA only to genes that had been shown to be bound by HoxA9 in their vicinity and whose expression either decreased or increased by $>1.5$ fold upon 4OHT withdrawal in HoxA9-ER/Meis1expressing cells (Huang et al. 2012). Importantly, we found that HoxA9-occupied genes respond to UNC0638 treatment and HoxA9 withdrawal (by removal of 4OHT) predominantly in the same way and that this overlap is highly significant in both directions (Fig. $4 \mathrm{C}, \mathrm{D})$. Taken together, these data demonstrate that G9a partakes in the regulation of HoxA9-dependent gene expression in AML cells, suggesting that the observed phenotypes in UNC0638-treated AML cells are at least partially caused by the attenuation of a HoxA9-dependent gene signature.

\section{Sensitivity to G9A/GLP inhibition is conserved in human $A M L$ specimens}

To assess whether G9A inhibition also affects the growth of human AML cells, we cultured primary human AML cells (normal karyotype, NPM1 $1^{\text {wt }} / F L T 3^{\text {wt }}$ ) in the presence or absence of UNC0638 for up to $7 \mathrm{~d}$. Reminiscent of our observation with murine $A 9 M$ cells, UNC0638 inhibited human AML cell proliferation (Fig. 5A-C) and triggered differentiation. This was evident morphologically (Fig. 5D) and from an increase in the mast cell surface marker $F c \in R 1 \alpha$ (Fig. 5E). In addition, UNC0638 treatment of human mobilized CD $34^{+}$HSPCs plated in methylcellulose led to a characteristic reduction in colony size identical to that observed in murine $G 9 a^{-1-(\text { Vav })}$ progenitor cultures (Supplemental Fig. S8). To perform a more representative assessment of G9A's requirement in human AML proliferation, we tested the response of 15 additional and genetically diverse primary AML specimens toward 
A
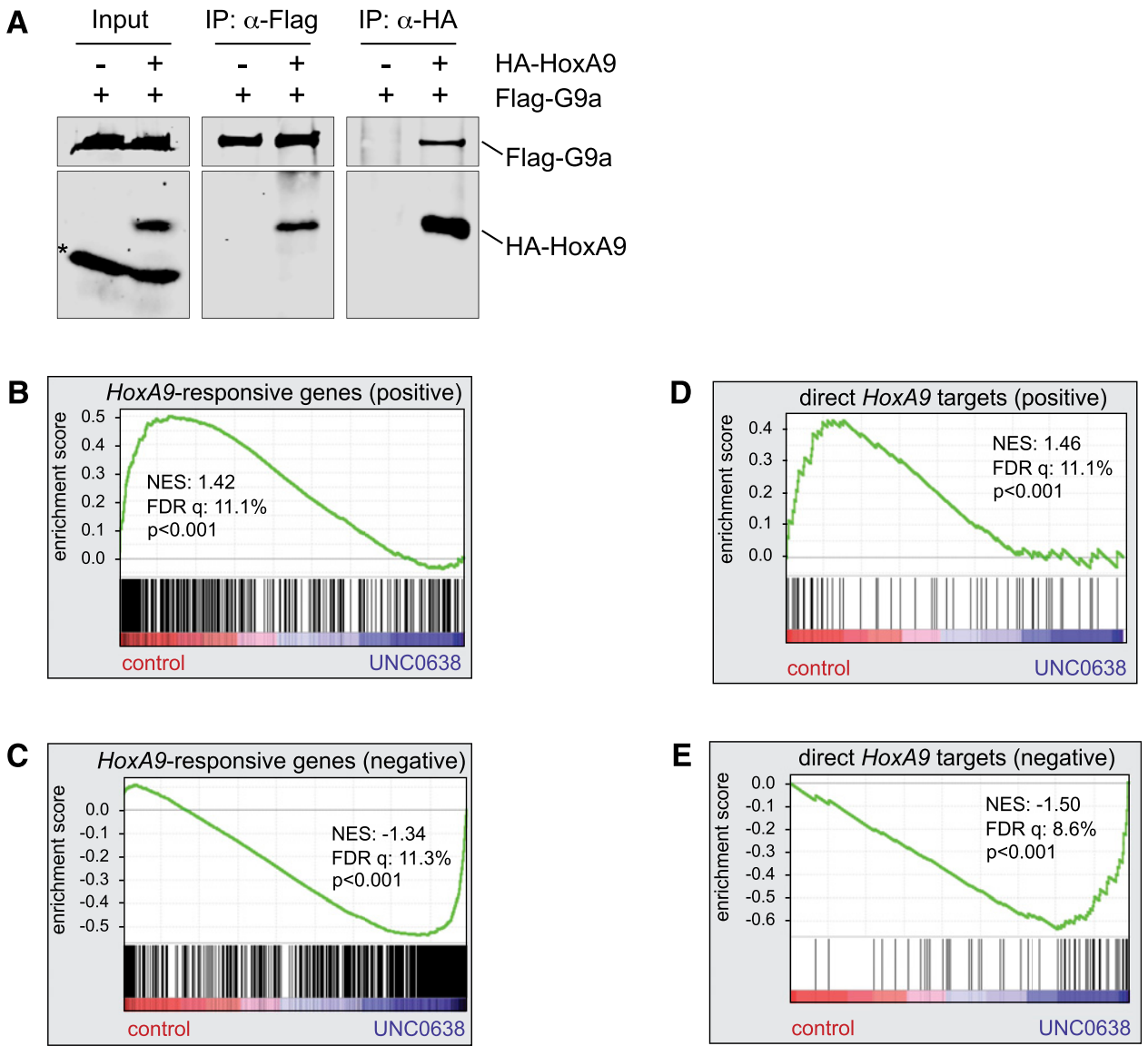

Figure 4. G9a regulates HoxA9-dependent gene expression. (A) Protein-protein interaction between HoxA9 and G9a. Flag-G9a and HA-HoxA9 were expressed in $293 \mathrm{~T}$ cells by transient transfection as indicated. Whole-cell extracts from transfected cells (left panel) or immunoprecipitated material from anti-Flag (middle panel) or anti-HA (right panel) immunoprecipitations were subjected to Western analysis using anti-Flag or anti-HA antibodies to visualize G9a (top) and HoxA9 (bottom), respectively. Robust reciprocal interaction between G9a and HoxA9 were detected. (B-E) GSEA plot evaluating changes in gene expression in $A 9 M$ cells subjected to $1 \mu \mathrm{M}$ UNC0638 (5 d). In $B$, genes that are down-regulated $\geq 1.5$-fold upon HoxA9 inactivation in Huang et al. (2012) correlate with control-treated $A 9 M$ cells and are predominantly down-regulated upon UNC0638 treatment. Conversely, in $C$, genes that are up regulated $\geq 1.5$-fold upon HoxA9 inactivation correlate with genes down-regulated in UNC0638-treated $A 9 M$ cells. In $D$ and $E$, GSEA was restricted to direct targets of HoxA9 according to Huang et al. (2012); i.e., genes that were both bound by HoxA9 and changed expression \pm 1.5 -fold upon HoxA9 inactivation. (NES) Normalized enrichment scores; (FDR Q-values) false discovery rate Q-values, indicating the likelihood of an applied gene set with the indicated NES represents a false-positive finding.

UNC0646, an improved version of the UNC0638 G9A/ GLP inhibitor (Liu et al. 2011). We detected growthsuppressive activity of UNC0646 in all tested samples, albeit to varying degrees, with $\mathrm{IC}_{50}$ values ranging from $0.58 \mu \mathrm{M}$ to $3.73 \mu \mathrm{M}$ (Fig. 5F; Supplemental Fig. S9). Together, these results indicate that our findings in murine AML models can be extended to humans, demonstrating that G9A/GLP-dependent methylation is an important determinant of human AML proliferation.

\section{Discussion}

Our data demonstrate that G9a/GLP-dependent methylation plays an important role in the efficient repression of terminal differentiation programs in AML and thus for efficient LSC self-renewal and proliferation. Strikingly,
LSCs exhibit a selective dependency on G9a compared with normal HSCs. This is consistent with the notion that oncogenic mutations of IDH1/2 (Mardis et al. 2009) result in elevated levels of histone marks like H3K9me2 deposited by G9A and GLP via inhibition of corresponding histone demethylases (Lu et al. 2012). Based on the results presented in this study, it is tempting to speculate that in an AML context, mutant IDH1/2 might specifically modulate target gene expression of HOXA9 and/or other transcription factors such as EVI-1, MYB, or MYC, whose roles in the pathogenesis of AML are at least in part mediated by G9A. While this would predict a more pronounced sensitivity of IDH1/2 mutant AML cells to inhibitors of G9A/ GLP or other methyltransferases, testing of much larger cohorts of genetically characterized human AML specimens is necessary to substantiate this hypothesis. 
Lehnertz et al.
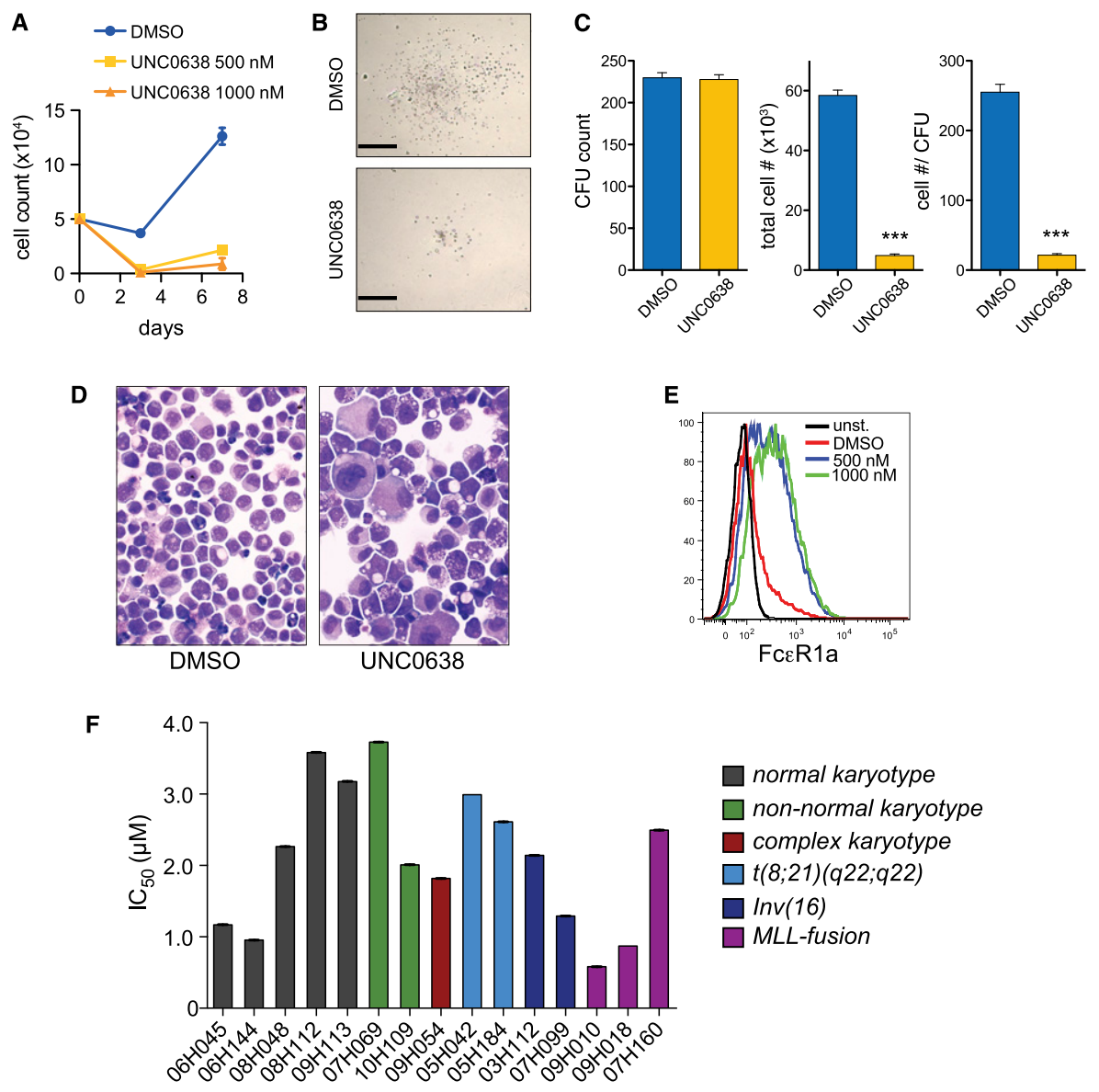

Figure 5. Sensitivity to G9A inhibition is conserved in human AML cells. (A) Growth inhibition of primary human AML cells in response to UNC0638 treatment. AML cells $\left(5 \times 10^{4}\right.$; normal karyotype, M1 AML, and NPM1 $\left.1^{\text {wt }} / F L T 3^{\text {wt }}\right)$ were plated in the presence of DMSO or $1 \mu \mathrm{M}$ UNC0638 and counted after 3 and $7 \mathrm{~d}$. Data represent mean value of four independent cultures for each time point; error bars represent standard deviations. (B) Clonal human AML growth is inhibited by UNC0638 treatment. AML cells (same as in $4 \mathrm{~d}$ ) were plated in methylcellulose-based AML medium and scored after $16 \mathrm{~d}$ of culture. Representative colonies are shown. Bar, $1 \mathrm{~mm}$. (C) UNC0638 treatment resulted in a dramatic decrease of cellular proliferation indicated by an $\sim 10$-fold reduction in both total and per-colony cell numbers. The outcome of $10^{3}$ cells plated per 2-mL culture is plotted. $(D)$ G9A inhibition causes differentiation of human AML cells. Primary human AML cells were cultured in liquid cytokine-containing medium in the presence of (1:10,000) DMSO or $1 \mu \mathrm{M}$ UNC0638 for $5 \mathrm{~d}$. Representative cytospin preparations are shown, indicating widespread differentiation upon G9A inhibition. (E) UNC0638 causes up-regulation of $F c \epsilon R 1 \alpha$, indicative of differentiation along the mast cell lineage. (F) UNC0646 exhibits growthsuppressive activity across different subclasses of human AML. Diagnostic AML samples ( $n=15)$ were treated with UNC0646 for $5 \mathrm{~d}$ in a threefold serial dilution setup. IC $_{50}$ values were calculated relative to DMSO control-treated samples and are plotted. Error bars represent $95 \%$ confidence intervals. Additional information on genotypes and dose response curves of the respective samples are provided in Supplemental Figure S9.

Furthermore, it remains controversial to what extent global H3K9me2 increases during cellular differentiation (Wen et al. 2009; Lienert et al. 2011), particularly since elevated H3K9me2 and H3K9me3 often correlate with the defective differentiation found in cancerous cells ( $\mathrm{Lu}$ et al. 2012). This controversy is further spurred by the observation that G9A/GLP inhibition can help to maintain the undifferentiated state of human HSCs under ex vivo culture conditions (Chen et al. 2012). Our data suggest that the cellular functions of G9a-dependent histone methylation are highly context-dependent and aid the stabilization of transcription programs that are specified by developmental transcription factors such as HoxA9 under normal or malignant circumstances.
From a practical perspective, this study reveals a novel and specific G9a function that is relevant to human biology and disease. By showing that G9a/GLP deletion selectively affects the proliferation of AML cells without detectable adverse effects on HSC function, our data emphasize the pharmacological inhibition of G9A/GLP as a potential targeted therapy.

\section{Materials and methods}

\section{Mouse strains}

G9 $a^{f 1}$ mice (Lehnertz et al. 2010), Vav-Cre mice (Stadtfeld and Graf 2005), and R26-YFP mice (Ye et al. 2003) were described earlier, and $\mathrm{Mx}$-Cre mice were obtained from Jackson Laboratory. 
All strains were maintained on a pure C57/B6 background and used between 6 and 12 wk of age. All procedures were conform with institutional guidelines.

\section{Antibodies for Western analysis}

Antibodies used for Western analysis were anti-G9a (clone A8620A, R\&D Systems; clone C6H3, Cell Signaling Technology), anti-GLP (clone B0422, R\&D Systems), anti-H3H9me2 (ab1220, Abcam), anti-H3 (ab1791, Abcam; clone C6H3, Cell Signaling Technology), anti-Flag (clone M2, Sigma-Aldrich), and anti-HA (clone 12CA5, Roche Applied Science).

\section{Progenitor growth assay}

Bone marrow cells were plated at $2 \times 10^{4}$ cells per milliliter culture. Methylcellulose medium (M3434, Stem Cell Technologies) was either purchased or generated in-house. CFUs were scored at day 8 after plating.

\section{Competitive bone marrow transplantation experiments}

Bone marrow cells from age- and sex-matched mice were mixed 1:1 with YFP $^{-}$control $\left(G 9 a^{f l / f 1}\right)$ bone marrow cells. We transplanted $4 \times 10^{6}$ cells into lethally irradiated $C D 45.1$ hosts. After 8 and $18 \mathrm{wk}$, we determined the ratios of YFP-negative $\left(G 9 a^{f l / f 1}\right)$ versus YFP-positive $\left(G 9 a^{+-(\text {Vav) }}\right.$ or $\left.G 9 a^{-/-(\text {Vav })}\right)$ cells in donorderived $\left(\mathrm{CD} 45.2^{+}\right)$granulocytes $\left(\mathrm{Gr}^{+}, \mathrm{Macl}^{+}\right)$, monocytes $\left(\mathrm{Gr}^{-}\right.$, $\left.\mathrm{Macl}^{+}\right)$, T cells $\left(\mathrm{CD}^{+}\right)$, and B cells $\left(\mathrm{B} 220^{+}\right)$using standard FACS antibodies on a BD LSRII.

\section{Bone marrow cell transduction and generation of mouse} AML models

MSCV HoxA9-ires-Meis PGK-Neo construct was obtained from Mark Kamps (University of California at San Diego). Retroviral infections were essentially done as described (Thorsteinsdottir et al. 2002). A9M-expressing cells were selected with $1.2 \mathrm{mg} / \mathrm{mL}$ G418 and injected into lethally irradiated CD45.1 mice. Recipients were monitored daily and sacrificed at humane AML endpoints according to institutional policy. For in vitro experiments, $A 9 M$ cells were cultured in mouse AML culture medium (DMEM, 15\%FBS, $100 \mathrm{ng} / \mathrm{mL} \mathrm{rmSCF}, 10 \mathrm{ng} / \mathrm{mL} \mathrm{rmIL-3,}$ $10 \mathrm{ng} / \mathrm{mL}$ rhIL-6, L-glutamine, penicillin/streptomycin, 1/100,000 $\beta$-mercaptoethanol; cytokines purchased from Stem Cell Technologies) at a plating density of $5 \times 10^{4}$ to $2 \times 10^{5}$ cells per milliliter.

\section{Secondary AML transplantation experiments}

Leukemic bone marrow cells from diseased primary recipient mice were extracted, cryopreserved, and then transplanted into sublethally irradiated secondary recipient mice. $\mathrm{Mx}-\mathrm{Cre}^{+} \mathrm{AML}$ cells were induced with four intraperitoneal injections of pIpC (400 $\mu \mathrm{g}$; Sigma) at days 3, 5, 7, and 9 after transplantation unless indicated otherwise.

\section{Immunoprecipitation studies}

HEK293T cells were subcultured at $60 \%$ confluence on 100 $\mathrm{mm}$ dishes and transfected with the indicated plasmids using Lipofectamine 2000 transfection reagent (Invitrogen). Fortyeight hours post-transfection, cells were rinsed twice with ice-cold PBS and incubated with RIPA lysis buffer (Santa Cruz Biotechnology). Fifteen microliters of Protein-A/G beads was added to the cell lysates for $30 \mathrm{~min}$ at $4^{\circ} \mathrm{C}$ for preclearing. Five- hundred micrograms of precleared protein was incubated with $4.0 \mu \mathrm{g}$ of indicated antibodies overnight at $4^{\circ} \mathrm{C}$, followed by adding $20 \mu \mathrm{L}$ of Protein-A/G beads. After a 3-h incubation, the beads were precipitated, washed once with RIPA buffer and twice with PBS, and boiled in $2 \times$ loading dye. Samples were separated by $10 \%$ SDS-PAGE and transferred to nitrocellulose membrane (Bio-Rad Laboratories). Blots were incubated with the indicated antibodies and visualized using the Odyssey infrared system (LI-COR Biosciences).

\section{Human AML cells}

All human AML samples used in these studies were collected by the Quebec Leukemia Cell Bank (BCLQ) with the informed consent and approval of the Leucegene project by the research ethics board of the Maisonneuve-Rosemont Hospital and Université de Montréal. Cryopreserved AML cells were thawed and cultured in serum-free conditions in the presence of SR1 (Alichem, catalog no. 41864) and UM729 (Sauvageau 2013). UNC0638/ UNC0646 were added to growth medium from a $5 \mathrm{mM}$ DMSO stock solution.

\section{Gene expression and statistical analyses}

G9a-dependent gene expression was assessed by comparing DMSO- and UNC0638-treated $A 9 M$ cells $(800 \mathrm{nM}, 5$ d, three biological replicates per condition). RNA was extracted with Trizol and analyzed on Affimetrix Mouse Gene 1.0 chip (accessible on Gene Expression Omnibus [GEO], GSE53894). HoxA9dependent gene expression files (Affymetrix Mouse Genome 430 2.0 chip) (Huang et al. 2012) were downloaded from GEO (GSE21299). CEL files were processed using the ExpressionFileCreator (RMA method) and PreprocessDataSet modules in the Genepattern suite (Broad Institute). GSEA analysis was done using $\log _{2}$ transformed expression values and the "difference of classes" setting with the provided gene sets (Supplemental Table 1). All further statistical analyses were done using Flowjo (Treestar) and Graphpad Prism.

\section{Acknowledgments}

We thank members of the Rossi and Sauvageau laboratories for critical reading of the manuscript, and the staff of the BRC, Terry Fox laboratory, and IRIC animal facilities for technical assistance. B.L. is supported by a Banting Post-doctoral Fellowship; C.P. is supported by a Cole Foundation Post-doctoral Fellowship. This work was financially supported by grants from Genome Quebec/Canada to J.H. and G.S. This research was also supported by funding from the US National Institutes of Health (R01GM103893) to J.J. This project is supported by a Terry Fox Program Project grant to R.K.H. and a grant from the Canadian Institutes of Health Research (CIHR) to F.R. B.L., C.P., L.S., and M.M. designed research, performed experiments, and analyzed data. L.Y., R.Z., J. Krosl, J. Kirschner, and P.R. performed experiments and analyzed data. F.L. and J.J. designed, generated, and provided UNC0638 and UNC0646. J.H. analyzed and provided primary human AML cells from the BCLQ to the Leucégène project in the G.S. laboratory. T.M.U., G.S., R.K.H., and F.M.R. supervised the research. B.L. and F.M.R. wrote the manuscript.

\section{References}

Arrowsmith CH, Bountra C, Fish PV, Lee K, Schapira M. 2012. Epigenetic protein families: A new frontier for drug discovery. Nat Rev Drug Discov 11: 384-400.

Barski A, Cuddapah S, Cui K, Roh T-Y, Schones DE, Wang Z, Wei G, Chepelev I, Zhao K. 2007. High-resolution profiling of 
histone methylations in the human genome. Cell 129: 823837.

Chaturvedi C-P, Somasundaram B, Singh K, Carpenedo RL, Stanford WL, Dilworth FJ, Brand M. 2012. Maintenance of gene silencing by the coordinate action of the H3K9 methyltransferase G9a/KMT1C and the H3K4 demethylase Jarid1a/ KDM5A. Proc Natl Acad Sci 109: 18845-18850.

Chen X, Skutt-Kakaria K, Davison J, Ou Y-L, Choi E, Malik P, Loeb K, Wood B, Georges G, Torok-Storb B, et al. 2012. G9a/ GLP-dependent histone H3K9me2 patterning during human hematopoietic stem cell lineage commitment. Genes Dev 26: 2499-2511.

Daigle SR, Olhava EJ, Therkelsen CA, Majer CR, Sneeringer CJ, Song J, Johnston LD, Scott MP, Smith JJ, Xiao Y, et al. 2011. Selective killing of mixed lineage leukemia cells by a potent small-molecule DOT1L inhibitor. Cancer Cell 20: 53-65.

Dawson MA, Kouzarides T. 2012. Cancer epigenetics: From mechanism to therapy. Cell 150: 12-27.

Delhommeau F, Dupont S, Valle Della V, James C, Trannoy S, Massé A, Kosmider O, Le Couedic J-P, Robert F, Alberdi A, et al. 2009. Mutation in TET2 in myeloid cancers. $N$ Engl $J$ Med 360: 2289-2301.

Delmore JE, Issa GC, Lemieux ME, Rahl PB, Shi J, Jacobs HM, Kastritis E, Gilpatrick T, Paranal RM, Qi J, et al. 2011. BET bromodomain inhibition as a therapeutic strategy to target c-Myc. Cell 146: 904-917.

Dong KB, Maksakova IA, Mohn F, Leung D, Appanah R, Lee S, Yang HW, Lam LL, Mager DL, Schübeler D, et al. 2008. DNA methylation in ES cells requires the lysine methyltransferase G9a but not its catalytic activity. EMBO I 27: 2691-2701.

Feldman N, Gerson A, Fang J, Li E, Zhang Y, Shinkai Y, Cedar H, Bergman Y. 2006. G9a-mediated irreversible epigenetic inactivation of Oct-3/4 during early embryogenesis. Nat Cell Biol 8: 188-194.

Gan T, Jude CD, Zaffuto K, Ernst P. 2010. Developmentally induced Mll1 loss reveals defects in postnatal haematopoiesis. Leukemia 24: 1732-1741.

Goyama S, Yamamoto G, Shimabe M, Sato T, Ichikawa M, Ogawa S, Chiba S, Kurokawa M. 2008. Evi-1 is a critical regulator for hematopoietic stem cells and transformed leukemic cells. Cell Stem Cell 3: 207-220.

Goyama S, Nitta E, Yoshino T, Kako S, Watanabe-Okochi N, Shimabe M, Imai Y, Takahashi K, Kurokawa M. 2009. EVI-1 interacts with histone methyltransferases SUV39H1 and G9a for transcriptional repression and bone marrow immortalization. Leukemia 24: 81.

Harris WJ, Huang X, Lynch JT, Spencer GJ, Hitchin JR, Li Y, Ciceri F, Blaser JG, Greystoke BF, Jordan AM, et al. 2012. The histone demethylase KDM1A sustains the oncogenic potential of MLL-AF9 leukemia stem cells. Cancer Cell 21: 473 487.

Huang Y, Sitwala K, Bronstein J, Sanders D, Dandekar M, Collins C, Robertson G, MacDonald J, Cezard T, Bilenky M, et al. 2012. Identification and characterization of Hoxa9 binding sites in hematopoietic cells. Blood 119: 388-398.

Krivtsov AV, Twomey D, Feng Z, Stubbs MC, Wang Y, Faber J, Levine JE, Wang J, Hahn WC, Gilliland DG, et al. 2006. Transformation from committed progenitor to leukaemia stem cell initiated by MLL-AF9. Nature 442: 818-822.

Kroon E, Krosl J, Thorsteinsdottir U, Baban S, Buchberg AM, Sauvageau G. 1998. Hoxa9 transforms primary bone marrow cells through specific collaboration with Meisla but not Pbx1b. EMBO J 17: 3714-3725.

Kubicek S, O'Sullivan RJ, August EM, Hickey ER, Zhang Q, Teodoro ML, Rea S, Mechtler K, Kowalski JA, Homon CA, et al. 2007. Reversal of H3K9me2 by a small-molecule inhibitor for the G9a histone methyltransferase. Mol Cell 25: 473-481.

Lawrence HJ, Helgason CD, Sauvageau G, Fong S, Izon DJ, Humphries RK, Largman C. 1997. Mice bearing a targeted interruption of the homeobox gene HOXA9 have defects in myeloid, erythroid, and lymphoid hematopoiesis. Blood 89: 1922-1930.

Lawrence HJ, Rozenfeld S, Cruz C, Matsukuma K, Kwong A, Kömüves L, Buchberg AM, Largman C. 1999. Frequent coexpression of the HOXA9 and MEIS1 homeobox genes in human myeloid leukemias. Leukemia 13: 1993-1999.

Lawrence HJ, Christensen J, Fong S, Hu Y-L, Weissman I, Sauvageau G, Humphries RK, Largman C. 2005. Loss of expression of the Hoxa-9 homeobox gene impairs the proliferation and repopulating ability of hematopoietic stem cells. Blood 106: 3988-3994.

Lehnertz B, Northrop JP, Antignano F, Burrows K, Hadidi S, Mullaly SC, Rossi FMV, Zaph C. 2010. Activating and inhibitory functions for the histone lysine methyltransferase G9a in T helper cell differentiation and function. I Exp Med 207: 915-922.

Ley TJ, Ding L, Walter MJ, McLellan MD, Lamprecht T, Larson DE, Kandoth C, Payton JE, Baty J, Welch J, et al. 2010. DNMT3A mutations in acute myeloid leukemia. $N$ Engl $I$ Med 363: 2424-2433.

Lienert F, Mohn F, Tiwari VK, Baubec T, Roloff TC, Gaidatzis D, Stadler MB, Schübeler D. 2011. Genomic prevalence of heterochromatic $\mathrm{H} 3 \mathrm{~K} 9 \mathrm{me} 2$ and transcription do not discriminate pluripotent from terminally differentiated cells. PLoS Genet 7: e1002090.

Liu F, Barsyte-Lovejoy D, Allali-Hassani A, He Y, Herold JM, Chen X, Yates CM, Frye SV, Brown PJ, Huang J, et al. 2011. Optimization of cellular activity of G9a inhibitors 7-aminoalkoxy-quinazolines. J Med Chem 54: 6139-6150.

Lu C, Ward PS, Kapoor GS, Rohle D, Turcan S, Abdel-Wahab O, Edwards CR, Khanin R, Figueroa ME, Melnick A, et al. 2012. IDH mutation impairs histone demethylation and results in a block to cell differentiation. Nature 483: 474478.

Mardis ER, Ding L, Dooling DJ, Larson DE, McLellan MD, Chen K, Koboldt DC, Fulton RS, Delehaunty KD, McGrath SD, et al. 2009. Recurring mutations found by sequencing an acute myeloid leukemia genome. N Engl J Med 361: 10581066.

Morin RD, Johnson NA, Severson TM, Mungall AJ, An J, Goya R, Paul JE, Boyle M, Woolcock BW, Kuchenbauer F, et al. 2010. Somatic mutations altering EZH2 (Tyr641) in follicular and diffuse large B-cell lymphomas of germinal-center origin. Nat Genet 42: 181-185.

Pinheiro I, Margueron R, Shukeir N, Eisold M, Fritzsch C, Richter FM, Mittler G, Genoud C, Goyama S, Kurokawa M, et al. 2012. Prdm3 and Prdm16 are H3K9me1 methyltransferases required for mammalian heterochromatin integrity. Cell 150: 948-960.

Sauvageau G. 2013. Pyrimido[4,5-b]indole derivatives and use thereof in the expansion of hematopoietic stem cells. PCT International patent application no. PCT/CA2013/050052.

Schenk T, Chen WC, Göllner S, Howell L, Jin L, Hebestreit K, Klein H-U, Popescu AC, Burnett A, Mills K, et al. 2012. Inhibition of the LSD1 (KDM1A) demethylase reactivates the all-trans-retinoic acid differentiation pathway in acute myeloid leukemia. Nat Med 18: 605-611.

Stadtfeld M, Graf T. 2005. Assessing the role of hematopoietic plasticity for endothelial and hepatocyte development by non-invasive lineage tracing. Development 132: 203213. 
Tachibana M, Sugimoto K, Nozaki M, Ueda J, Ohta T, Ohki M, Fukuda M, Takeda N, Niida H, Kato H, et al. 2002. G9a histone methyltransferase plays a dominant role in euchromatic histone $\mathrm{H} 3$ lysine 9 methylation and is essential for early embryogenesis. Genes Dev 16: 1779-1791.

Tachibana M, Ueda J, Fukuda M, Takeda N, Ohta T, Iwanari H, Sakihama T, Kodama T, Hamakubo T, Shinkai Y. 2005. Histone methyltransferases G9a and GLP form heteromeric complexes and are both crucial for methylation of euchromatin at H3-K9. Genes Dev 19: 815-826.

Thorsteinsdottir U, Mamo A, Kroon E, Jerome L, Bijl J, Lawrence HJ, Humphries K, Sauvageau G. 2002. Overexpression of the myeloid leukemia-associated Hoxa9 gene in bone marrow cells induces stem cell expansion. Blood 99: 121-129.

Tkachuk DC, Kohler S, Cleary ML. 1992. Involvement of a homolog of Drosophila trithorax by 11q23 chromosomal translocations in acute leukemias. Cell 71: 691-700.

Vedadi M, Barsyte-Lovejoy D, Liu F, Rival-Gervier S, AllaliHassani A, Labrie V, Wigle TJ, Dimaggio PA, Wasney GA, Siarheyeva A, et al. 2011. A chemical probe selectively inhibits G9a and GLP methyltransferase activity in cells. Nat Chem Biol 7: 566-574.

Wen B, Wu H, Shinkai Y, Irizarry RA, Feinberg AP. 2009. Large histone $\mathrm{H} 3$ lysine 9 dimethylated chromatin blocks distinguish differentiated from embryonic stem cells. Nat Genet 41: 246-250.

Ye $M$, Iwasaki $H$, Laiosa CV, Stadtfeld $M$, Xie H, Heck S, Clausen B, Akashi K, Graf T. 2003. Hematopoietic stem cells expressing the myeloid lysozyme gene retain long-term, multilineage repopulation potential. Immunity 19: 689-699.

Yuan Y, Wang Q, Paulk J, Kubicek S, Kemp MM, Adams DJ, Shamji AF, Wagner BK, Schreiber SL. 2012. A small-molecule probe of the histone methyltransferase G9a induces cellular senescence in pancreatic adenocarcinoma. ACS Chem Biol 7: 1152-1157.

Zuber J, Shi J, Wang E, Rappaport AR, Herrmann H, Sison EA, Magoon D, Qi J, Blatt K, Wunderlich M, et al. 2011. RNAi screen identifies Brd4 as a therapeutic target in acute myeloid leukaemia. Nature 478: 524-528. 


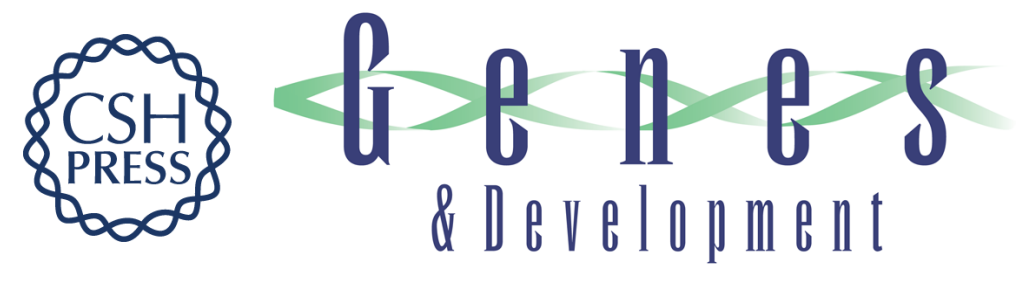

\section{The methyltransferase G9a regulates HoxA9-dependent transcription in AML}

Bernhard Lehnertz, Caroline Pabst, Le Su, et al.

Genes Dev. 2014, 28:

Access the most recent version at doi:10.1101/gad.236794.113

\section{Supplemental http://genesdev.cshlp.org/content/suppl/2014/02/14/28.4.317.DC1 Material}

References This article cites 40 articles, 12 of which can be accessed free at: http://genesdev.cshlp.org/content/28/4/317.full.html\#ref-list-1

Creative This article is distributed exclusively by Cold Spring Harbor Laboratory Press for the first Commons six months after the full-issue publication date (see

License http://genesdev.cshlp.org/site/misc/terms.xhtml). After six months, it is available under a Creative Commons License (Attribution-NonCommercial 3.0 Unported), as described at http://creativecommons.org/licenses/by-nc/3.0/.

Email Alerting Receive free email alerts when new articles cite this article - sign up in the box at the top Service right corner of the article or click here.

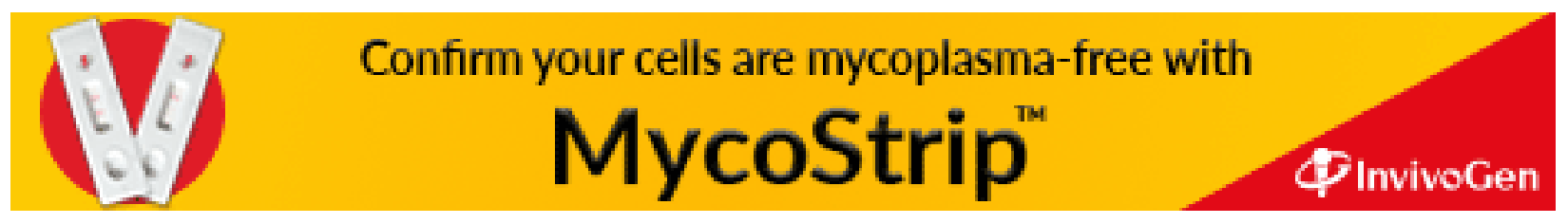

